\title{
Examining Academic Service using Importance Performance Analysis (IPA)
}

\author{
M. Said Saggaf \\ Sekolah Tinggi Ilmu Administrasi (STIA) \\ Puangrimaggalatung, Sengkang, Indonesia
}

Muhammad Darwis

Universitas Negeri Makassar

Makassar, Indonesia

\author{
Rudi Salam \\ Universitas Negeri Makassar \\ Makassar, Indonesia \\ Jamaluddin \\ Universitas Negeri Makassar \\ Makassar, Indonesia
}

\begin{abstract}
Measure of academic services is crucial in finding out the quality of service in every level of education. The objective of this study is providing an overview of academic service quality by using importance performance analysis (IPA). Thirty respondents involved in this study are students of Muhammadiyah Secondary School around South Sulawesi, Indonesia to assure the respondents' homogeneous. This study reveals that the academic services such as the availability of resources, the syllabus dissemination, teacher discipline, monitoring of students, and sharing information are still relatively low. This study exposes that the academic service, which makes students experiencing pleased is the principal who provides available time for parents to solve students' problem together with counselor. In addition, this study also finds that level of expectation is less important in affecting the students' satisfaction on academic service.
\end{abstract}

\section{Keywords- Academic Service, IPA}

\section{INTRODUCTION}

In the $1980 \mathrm{~s}$ the organization has done a quality management system to measure the performance of the organization [1], [2]. One way to measure the performance of the organization is using Importance Performance Analysis (IPA). The researchers are focusing research on Importance Performance Analysis (IPA) are [1]-[7]. The quality characteristics are based on their importance to facilitate the use of appropriate strategies based on the indicators.

The fundamental concept of the previous researches is on the measuring organizational performance in the particular company. Thus, the topic of study is leading to customer satisfaction in a company. However, this research focuses on organizational performance on academic services. The academic service is a subsystem that also affects the success of the learning process as an important part of education that will ultimately affect the output of an educational process. The learning process in an educational institution is influenced by the system of administrative, academic, and student.

Muhammadiyah Secondary School is one of the popular private educational foundation in Indonesia. Therefore, it is of course required a professional service to the students to compete with other public school. Hence, private school could help students being successful in their future career. Therefore, the availability of professional teacher is a mandatory that leading to students' satisfaction. In addition, professional service to students requires an improvement to facilitate students being prosperous in learning process.

Thus, it becomes very natural that the students always demand quality services, which meet the desires or needs of students in relation to the smoothness of their studies. However, the effort in providing professional service still under students' satisfaction as they complain the discrepancy of services provided. Similarly, in the learning process, providing professional service is constrained due to the process of academic service breaks up students' expectation. Based on preliminary observations that the quality of services provided required an expose are facilities and the quality of teachers.

\section{METHOD}

This study is a quantitate method focuses on exposing the academic service using Important Performance Analysis (IPA). Data collection techniques used questionnaires, interviews, documentation and observation. Data Collecting Instrument is a tool used to collect data. Because of the tool, the instrument can be a check list, questionnaire (open / closed questionnaires), interview guides and camera photos. The sampling technique used is multi-stage random sampling. Thirty respondents of Muhammadiyah Secondary School's students around South Sulawesi, Indonesia that involved in this study are homogeneous. Importance Performance Analysis is firstly introduced by [2] to measure the relationship between consumer perceptions and the priority of improving the quality of products/services that is known also as quadrant analysis. The tangible, responsiveness, assurance, empathy, and the reliability are aspects to measure in this study to measure the academic service quality [8].

\section{III.RESULTS}

The quality of academic services from five (5) aspects of the service is tangible, responsiveness, assurance, empathy, and the reliability [8]. Fife of these aspects consists of thirty five items or attributes of service quality. From these aspects, the researchers analyzed the deployment of four quadrants to 
... (ungum iv respondents' comments about the information provided as shown in Table 1 and Figure 1.

TABLE 1. ACADEMIC SERVICE BASED ON EXPECTATION AND FACTS

\begin{tabular}{|c|c|c|c|c|}
\hline \multirow{2}{*}{ Item } & \multirow{2}{*}{$\begin{array}{l}\text { Academic service } \\
\text { item }\end{array}$} & \multicolumn{2}{|c|}{ Mean score } & \multirow{2}{*}{ Quadrant } \\
\hline & & Expectation & Fact & \\
\hline 5 & References in library & 3.8 & 4.6 & $\mathrm{~A}$ \\
\hline 6 & Clean toilet & 3.9 & 4.7 & A \\
\hline 9 & $\begin{array}{l}\text { Teacher provides } \\
\text { syllabus }\end{array}$ & 3.9 & 4.7 & $\mathrm{~A}$ \\
\hline 12 & $\begin{array}{l}\text { Teacher comes on } \\
\text { time }\end{array}$ & 4.0 & 4.7 & $\mathrm{~A}$ \\
\hline 13 & $\begin{array}{l}\text { Academic staff } \\
\text { service }\end{array}$ & 4.0 & 4.8 & $\mathrm{~A}$ \\
\hline 14 & $\begin{array}{l}\text { Quality of acad. Staff } \\
\text { service }\end{array}$ & 4.0 & 4.9 & $\mathrm{~A}$ \\
\hline 27 & $\begin{array}{l}\text { Care on students' } \\
\text { problem }\end{array}$ & 4.0 & 4.6 & A \\
\hline 28 & $\begin{array}{l}\text { Watch students' } \\
\text { progress }\end{array}$ & 4.0 & 4.7 & $\mathrm{~A}$ \\
\hline 31 & $\begin{array}{l}\text { Understand students' } \\
\text { talent }\end{array}$ & 4.0 & 4.8 & $\mathrm{~A}$ \\
\hline 32 & $\begin{array}{l}\text { Provide school } \\
\text { profile }\end{array}$ & 4.0 & 4.7 & $\mathrm{~A}$ \\
\hline 7 & Worship facilities & 4.1 & 4.6 & $\mathrm{~B}$ \\
\hline 18 & Parents' relationship & 4.3 & 4.6 & $\mathrm{~B}$ \\
\hline 19 & Provide first aid & 4.1 & 4.7 & $\mathrm{~B}$ \\
\hline 20 & Insurance & 4.1 & 4.6 & $\mathrm{~B}$ \\
\hline 21 & $\begin{array}{l}\text { Academic staff' } \\
\text { politeness }\end{array}$ & 4.2 & 4.6 & $\mathrm{~B}$ \\
\hline 23 & $\begin{array}{l}\text { School's counselor' } \\
\text { behavior }\end{array}$ & 4.3 & 4.7 & $\mathrm{~B}$ \\
\hline 35 & $\begin{array}{l}\text { Give positive } \\
\text { response to students' } \\
\text { problem }\end{array}$ & 4.1 & 4.7 & $\mathrm{~B}$ \\
\hline 1 & Clean classroom & 3.9 & 4.5 & $\mathrm{C}$ \\
\hline 2 & $\begin{array}{l}\text { Comfortable } \\
\text { classroom }\end{array}$ & 3.9 & 4.2 & $\mathrm{C}$ \\
\hline 3 & Learning facilities & 3.6 & 4.3 & $\mathrm{C}$ \\
\hline 4 & Comfortable library & 3.7 & 4.5 & $\mathrm{C}$ \\
\hline 8 & Transparent financial & 4.0 & 4.5 & $\mathrm{C}$ \\
\hline 10 & $\begin{array}{l}\text { Good teaching } \\
\text { materials }\end{array}$ & 4.0 & 4.5 & $\mathrm{C}$ \\
\hline 11 & Good feedback & 4.0 & 4.4 & $\mathrm{C}$ \\
\hline 16 & Scholarship & 3.9 & 4.3 & $\mathrm{C}$ \\
\hline 24 & Provide homework & 3.8 & 4.2 & $\mathrm{C}$ \\
\hline 25 & Effective teaching & 3.8 & 4.1 & $\mathrm{C}$ \\
\hline 26 & Sanction & 3.8 & 4.5 & $\mathrm{C}$ \\
\hline 29 & Teachers' care & 4.0 & 4.5 & $\mathrm{C}$ \\
\hline 15 & $\begin{array}{l}\text { Provides school's } \\
\text { counselor }\end{array}$ & 4.2 & 4.5 & $\mathrm{D}$ \\
\hline 17 & $\begin{array}{l}\text { Teachers' care of } \\
\text { students' problem on } \\
\text { academic }\end{array}$ & 4.1 & 4.5 & $\mathrm{D}$ \\
\hline 22 & $\begin{array}{l}\text { Students' problem } \\
\text { solved by teacher }\end{array}$ & 4.4 & 4.5 & $\mathrm{D}$ \\
\hline 30 & $\begin{array}{l}\text { Teacher is open } \\
\text { minded }\end{array}$ & 4.1 & 4.3 & $\mathrm{D}$ \\
\hline 33 & $\begin{array}{l}\text { School provide } \\
\text { website }\end{array}$ & 4.1 & 4.3 & $\mathrm{D}$ \\
\hline 34 & $\begin{array}{l}\text { Provide complain } \\
\text { room }\end{array}$ & 4.1 & 4.2 & $\mathrm{D}$ \\
\hline
\end{tabular}

Based on the Table 1 above, the quality of academic service is indicated by the mean score of expectation and facts. By finding out the mean score, the next step is converting these mean score to Cartesian diagram as in Figure 1 below. Cartesius diagram is a diagram that shows the expectations and the reality of the academic services provided by the service providers [9].

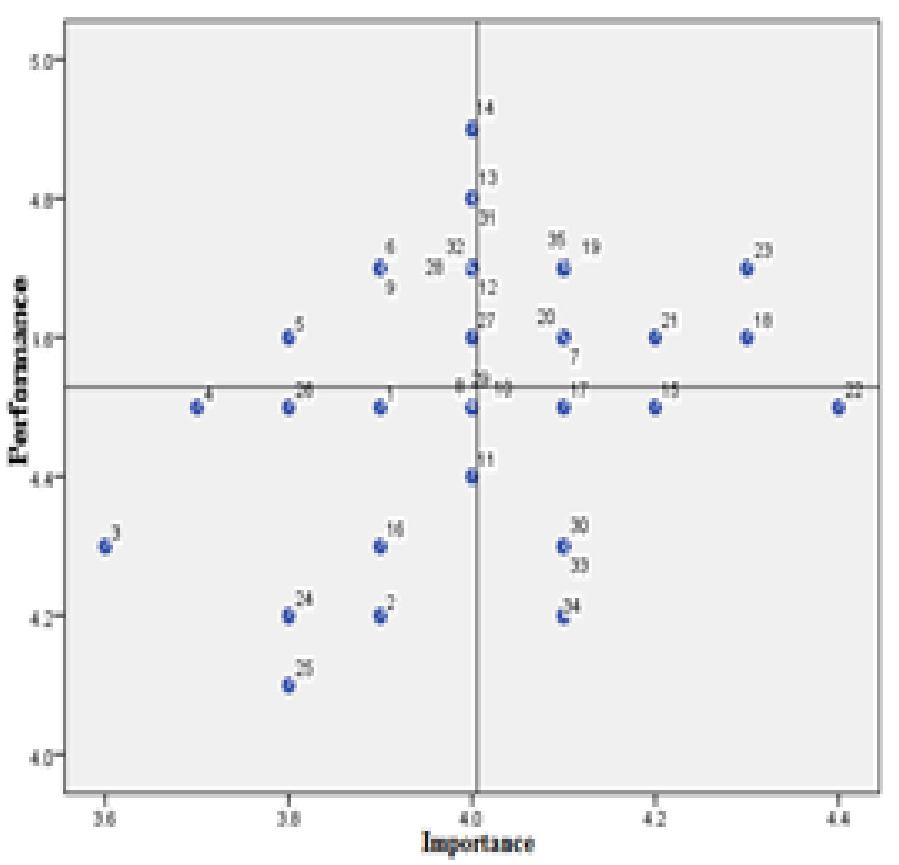

Figure 1. Cartesius diagram of academic service item

The results of the study showed that the good quality of academic service based on the four quadrants is based on quadrant A, B, and D [10]. Table 1 and Figure 1 indicated that the availability of academic services such as reference in library, clean toilet, teacher provides syllabus, teacher comes on time, academic staff service, quality of academic staff service, care on students' problem, watch students' progress, understanding students' talent, and provides school profile are still relatively low or in quadrant A. Meanwhile, the items belong to quadrant $\mathrm{B}$ or academic service items present students' satisfaction are worship facilities, parents' relationship, provide first aid, insurance, academic staff politeness, school counselor behavior, and give positive response to students' problem. In quadrant D or aspects of the level of expectation, which are less important, but it can affect student satisfaction are school provides counselor teacher, teachers' care of students' problem on academic, students' problem solved by teacher, teacher is open minded, school provides website, and complain room. This is consistent with the study [11] states that to address student issues must begin with internal factors in schools such as homeroom. Further influenced by external factors such as social media and societies are invited to mingle. In addition, this study is supported by other researchers as revealed by [12] stating that there are two factors that affect student problems are internal factors in school and factors in the field. 


\section{CONCLUSION}

This study indicated that the academic services regarding reference in library, clean toilet, teacher provides syllabus, teacher comes on time, academic staff service, quality of academic staff service, care on students' problem, watch students' progress, understanding students' talent, and provides school profile are still relatively low. Meanwhile, worship facilities, parents' relationship, provide first aid, insurance, academic staff politeness, school counselor behavior, and give positive response to students' problem are categorized as academic service items represent students' satisfaction. Ultimately, school provides counselor teacher, teachers' care of students' problem on academic, students' problem solved by teacher, teacher is open minded, school provides website, and complain room are considerably less important, but they can affect student satisfaction.

\section{REFERENCES}

[1] H. Y. Hu, Y. C. Lee, T. M. Yen, and C. H. Tsai, "Using BPNN and DEMATEL to modify importance-performance analysis model - A study of the computer industry," Expert Syst. Appl., vol. 36, no. 6, pp. 9969-9979, 2009.

[2] J. a Martilla and J. C. James, "Importance-Performance Analysis," J. Mark., vol. 41, no. 1, pp. 77-79, 1977.

[3] L. L. Berry and A. Parasuraman, "Prescriptions for a service quality revolution in America," Organ. Dyn., vol. 20, no. 4, pp. 5-15, 1992.

[4] D. Breiter and A. Milman, "Attendees' needs and service priorities in a large convention center: Application of the importance-performance theory," Tour. Manag., vol. 27, no. 6, pp. 1364-1370, 2006.

[5] R. J. Angell, T. W. Heffernan, and P. Megicks, "Service quality in postgraduate education," Qual. Assur. Educ., vol. 16, no. 3, pp. 236$254,2008$.

[6] N. Kim and S. R. Lee, "Determining the priority of self-regulated learning ability development for engineering college students using IPA," in Proceedings of 2015 International Conference on Interactive Collaborative Learning (ICL), 2015, no. September, pp. 589-592.

[7] A. Shafaei and N. A. Razak, "What matters most: importanceperformance matrix analysis of the factors influencing international postgraduate students' psychological and sociocultural adaptations," Qual. Quant., vol. 50, no. 5, pp. 1-20, 2016.

[8] L. F. Pitt, R. T. Watson, and C. B. Kavan, "Service Quality: A Measure of Information Systems Effectiveness," MIS Q., vol. 19, no. 2, pp. 173-187, 1995.

[9] K. Behrend, "Gromov-Witten invariants in algebraic geometry," Invent. Math., vol. 127, no. 3, pp. 601-617, 1997.

[10] M. Peris-Ortiz and J. Álvarez-García, Action-Based Quality Management: Strategy and Tools for Continuous Improvement. Springer International Publishing, 2014.

[11] S. Aisyah and S. Ag, Perkembangan peserta didik dan bimbingan belajar. Deepublish, 2015.

[12] I. Usman, "Perilaku Bullying Ditinjau Dari Peran Kelompok Teman Sebaya Dan Iklim Sekolah Pada Siswa Sma Di Kota Gorontalo," Gorontalo Fak. Ilmu Pendidikan. Skripsi. Diakses dari http//libraryung. ac. id/diunduh pada tanggal, vol. 20, 2008. 